\title{
THE LITERARY PROGENITORS OF AMERICAN FEMINISM: IMPLICATIONS FOR THE CONTEMPORARY PASHTUN WOMEN IN PAKISTAN
}

\author{
Imran Ali $^{1 *}$, Bahrmand Shah ${ }^{1}$, Sobia Rana ${ }^{1}$ and Ramzan Shahid ${ }^{2}$ \\ ${ }^{1}$ Quaid-i-Azam University Islamabad and English Department, University of California at Berkeley, USA \\ ${ }^{2}$ Department of Pol. Science and International Relations, University of Gujrat, Pakistan
}

\begin{abstract}
The mid- $19^{\text {th }}$ century proved a prime time for the question of women's equality in the U.S., that was voiced by many scholarly fields as diverse as history, anthropology, sociology, gender studies, literature, etc.,and particularly the American novel-The Scarlet Letter; Little Women; The Portrait of a Lady; The Awakening, and Sister Carrie. These novels through their multi-faceted and lifelike protagonists systematically instituted the base of American feminism atits different evolutionary phases. The study explores how these five mid- $19^{\text {th }}$ century American novels dealt with the issue of women's equality through the lenses of New Historicism and Gender Studies. Through close socio-historical readings of these novels, I will discuss how struggle for women's rights was presented in the select novels, how closely these depictions are aligned with actual social conditions, and how the novels facilitated a social change regarding woman's equality. Finally the study signifies how the experience can augment the cause of contemporary Pashtun women's rights in Pakistan, which is a burning issue at the moment.
\end{abstract}

Keywords: Progenitors, American Feminism,19 $9^{\text {th }}$ Century Novel, Pashtun Women

\section{Introduction}

Though Olympes de Gouge (d. 1791), Mary Wollstonecraft (d. 1797) and Jane Austen (d. 1817) are considered foremothers of the modern feminism, a few researchers locate the origin of feminism in ancient Greece with Sappho (d. c. 570 BCE), or the medieval world with Hildegard of Bingen (d. 1179) or Christine de Pisan (d. 1434) (Ramptonn.p). All these people advocated for the dignity and basic human potential of the female sex. Since the beginning, there were many scattered references/events - like Margaret Fuller's "The Great law Suit: Men versus Men; Women versus Women" and Women in the Nineteenth Century (1845), related to the role of women in American history; Lucretia Mott and Elizabeth Cady Stanton's "The Seneca Fall Woman's Rights Convention" (1848) was the head- start of an organized gender-equality movement in America in which Elizabeth Cady Stanton outlined the new movement's ideology and strategies (Ramptonn.p). Affected by the phenomenon, the mid $19^{\text {th }}$ century American novelists-Nathaniel Hawthorne (1804-1864), Louisa May Alcott (1832-1888), Henry James (1843-1916), Kate Chopin (1850-1904), and Theodore Dreiser (1871-1945), who were already grappling with the emergent feminist movement, penned down The Scarlet Letter (1850), Little Women (1869), The Portrait of a Lady (1881), The Awakening (1899) and Sister Carrie (1900) respectively. These texts, through their multi-faceted and real-life protagonists: Hester Prynne, Jo March, Isabel Archer, Edna Pontellier and Carrie Meeber, step-by-step, advanced the cause of American feminism in its budding stages in terms of social, sexual, economic, and political equality. The content and contemporary critical responses show these texts systematically address the question of women's equality from many nuance angles. Both the American history and the novel seem to support the phenomena that the problem of the question of woman equality existed in the American society at that time. These novelists were part of the very society where the problem existed. Through close socio-historical readings of these five novels, the paper will discuss how struggle for women's rights was presented and how closely those depictions were aligned with social conditions. In sum, the study explores how the select novels dealt with the issue of women's equality through the lenses of 
New Historicism, and Gender Studies. Primarily, New Historicism through Will in the World: How Shakespeare Became Shakespeare (Stephen Greenblatt, 2004) positions the study in mid $19^{\text {th }}$ century. It will further clarify how the novels and contemporary criticism were influenced by the ongoing trends in the society of that time. The study will also explore how the movement toward woman's equality was manifested in late $19^{\text {th }}$ century American society. Following the historical sections, I focus on how the question of woman's equality was addressed at that time. The next step is a close reading with the lens of The Resisting Reader: A Feminist Approach to American Fiction(Judith Fetterly 1977) to examine how these manifestations of women's equality movement were reflected in the five novels. Finally, I ask how the novels facilitated a social change regarding woman's equality. I will analyze these novels through the lens of gender equality to compare the question of equality before and after the publications of the novels. At the end, I will switch the discussion to the struggle of these fictional heroes that how they could inspire the Pashtun women in Pakistan, who are beginning to voice for their basic rights.

Study of the American novel in the second half of the $19^{\text {th }}$ century has been researched exhaustively because it is what F.O. Matthiessen calls the American Renaissance (from about 1830 to around the Civil War), a golden age of American literature (Baym 3; Vol. B). There are, however, some areas that are not properly explored yet. There may be substantial feminist scholarship, but the five novels have not been studied in relation to one another or through the two historical lenses under a full-fledged project yet. Next, the comparison of their implications for the contemporary Pashtun women in Pakistan is totally a novel idea.

The study is to establish the degree in which the select novels in a systematic way reflected the woman's question and, at the same time, raised awareness about the further progress of woman's equality. Next, the study highlights the role of the late $19^{\text {th }}$ century American novel in contributing to a reevaluation of the role of women both then and now. Furthermore, the research paper secures a prominent place for the mid $19^{\text {th }}$ century American novel in laying the foundation for American feminism and influencing the contemporary Pashtun women's struggle for their rights in Pakistan.

\section{Context}

The mid $19^{\text {th }}$ century could be called a catharsis of American potential that started before the Civil War but sprung up with the end of it overturning the entire fabric of American society. Society, economy, politics, architecture, literature, history, norms, values, education, war, industry, traveling, living, etc. were all profoundly affected by the end of slavery and the attempts to heal the rift between North and South. The mid $19^{\text {th }}$ century saw the introduction of many new ideas, not least of which was the argument for women's rights. Although this was the beginning of a lengthy and hazardous struggle, women were set on path to equality. Throughout the mid $19^{\text {th }}$ century women grappled with an entrenched patriarchy that defined women as objects to be owned by fathers and husbands. The domestic ideal posited that women were confined to domestic sphere producing andrearing children, and serving other family members (Woloch 241). Marriage was another societal or familial prerequisite that had to frame a woman's identity in the society. Women like Jane Addams called it the "family claim" that required a woman to marry and then care for her home and family (Woloch 256). Addams rebelled against this patriarchal requirement and paved the way for others. Nancy Woloch explores how the marriage rate fell over the mid19 $9^{\text {th }}$ century and a tendency towards single life rose (221). Along with domestic confinement, women's sexual rights were openly usurped and silenced. Claudia Durst Johnson explores in Social Issues in Literature: Women's Issues in Nathaniel Hawthorne's The Scarlet Letter:

By the nineteenth century. . .women were more repressed and limited in their sexuality. At the time Hawthorne composed The Scarlet Letter, the prevailing belief was that decent women did not enjoy sex but submitted to it out of duty. Women were thus divided into two categoriesAngels or Whores — and there was nothing in between. (10-11)

Women also had problems in job sectors. They were not thought capable of performing skillful work and were paid almost 50 percent less than their male counterparts. They worked under terrible conditions and wereat the 
mercy of administration, to be fired and hired, any time. In this regard, women's settlements and unions began to play a significant role for their rights at work places. Not having the right to vote, they could not raise their voices through legal means. Though the formal struggle for their equality started with The Seneca Falls Declaration of Sentiments 1848, the declaration did not directly demand for the right to vote. Instead, it mainly focused on attitude towards women and marital and extra-marital issues. After the Civil War, the Seneca Fall Declaration remained the major statement of women's demands for equality. It was an important document until 1920 when the $19^{\text {th }}$ Amendment awarded women the right to vote. (Woloch 226). It was a common opinion that women's natural place was at home where they were socially, sexually, economically and politically dependent on males (Woloch 221). Like other scholarships, texts with feminist issues were produced both by male and female literary writers to voice the women's cause.

\section{Contemporary Pashtun Women's Position in Pakistan}

Pahtunsare a major ethnicity both in Pakistan and Afghanistan. In Pakistan, Pashtuns are found along the border of Afghanistan in Khyber Pukhtunkhwa (KP), Federal Administered Tribal Area, Balochistan and Karachi. Pastunshave a strict patriarchal society with limited social, sexual, economic and political rights for women. Clutched by religious romance and strict cultural constraints, Pashtuns women in Pakistan are trying to voice from different platforms: literature, NGOs, and women's activism, but the pace is slower than what it should be. Although the rising level of education and social media have played a satisfactory role in softening these patriarchal shackles, it could not be denied that the Pashtun society is still in men's formidable clutches.

The story of injustices commences with a Pashtun woman at the time of her birth, which is commonly taken as a bad omen for the family (Yousafzai 20). Noor Sanauddin explores extreme gender bias towards women in Pashtun proverbs. For example, "A home that does not have a male child should be demolished" or "A girl's father is never at rest" (308). There may be variations in the degree of Pashtun women's freedom of movement, but the majority of women in Pashtun societies are confined to homes: their role begins and ends in domestic sphere. At a very young age, girls are required to learn all the technicalities of managing a house. They are advised to look after the younger babies in the family in order to train them for their future domestic and maternal obligations. Confined to roles mandated by patriarchy, women face unfair discrimination in Pashtun Society (PPAF 24). They have a limited say in familial decisions-"Women toil, while men decide"- that's how one interviewee describes Pashtun gender roles.

The issue of Pashtun women's education is immensely important because most of Pashtun women's problems stem from illiteracy. The need of women's education is what MalalaYousafzai, the Noble Laureate, who also hails from Pashtun ethnicity (Swat, Pakistan), insists upon. In her telephone interview with the author, she attested that the lack of awareness in Pashtun women, who are mostly uneducated ${ }^{1}$, makes them vulnerable to their male masters. Pashtun women, with a feminist awareness that comes directly from education, could be in a better position to fight for their rights.

With some degree of softening in recent years, women's consent in marriage has been the most critical issue in Pashtun culture since the genesis of Pashtun society. Both males and females have a limited say in marriagewhich is usually arranged by families - but still men are asked and women are informed (Yousafzai21). The refusal of a marriage proposal by a Pashtun woman is usually taken a sign of infidelity that, in some cases, leadsto her death (Yousafzai66-67). Subsequently, divorce is a social stigma in Pashtun society; it plagues both the life of a male and a female; therefore, divorce is a rare phenomenonin Pashtun culture. In Pashtun societies,

${ }^{1}$ Literacy rates are 50 percent for the overall population, with 73 percent for males and 27 percent for females during the year 2012-13. Around 38 percent of girls fail to register in schools (PPAF 10). 
the ratio of domestic violence is the highest as compared to other crimes. Up to 70 percent of cases reported at the police stations are related to domestic violence and usually triggered by honor issues (PPAF 24, 26).

Besides, Pashtun women are economically dependent on men and bear a huge amount of mental stress (PPAF 25, 26). There are limited job opportunities for women. They are commonly allowed to work in homelike spheres that could be found most often in education and health. The story does not end here. Pashtun women are done the worst injustices in property inheritance. Both the law and religion assure a woman's inheritance, but the Pashtun culture strongly opposes it. For a Pashtun woman, political participation is also highly objectionable. The society does not allow it. The political realm is a masculine department, just as 'home' is a feminine one. Women have the right to vote, but not the authority to practice it.

\section{Discussion}

\section{Nathaniel Hawthorn's The Scarlet Letter 1850}

Nathaniel Hawthorne (1804-1864) was born in Salem, Massachusetts. As a renowned American short-story writer and novelists, Hawthorne occupies a central place among Melville, Henry James, William Dean Howells and William Faulkner. His father's early death left him to his mother and two sisters, who, in some degree along his female friends, influenced his view about women. Hawthorne's removal from the Salem Custom House and his mother's death pushed him to the composition of The Scarlet Letter (1850). Hester's intellectual independence, female eroticism, and the concept of single motherhood; he borrowed from his female friends: Elizabeth Peabody (his sister-in-law), Margaret Fuller (author of Women in the Nineteenth Century,1845), and Francis Kemble (a former actress); his sister, Eliza; and his wife, Sophia Peabody (Idol Jr. 17-18; Erlich 25). David B. Kesterson believes Margaret Fuller inspired Hawthorne's many protagonists, but Hester Prynne, the protagonist in Scarlet Letter, bears close similarity to her character (34). Though Hawthorne is controversial in terms of his opinion about women's position, he appears with a different stance in The Scarlet Letter. The Scarlet Letter is a story of a young woman, Hester Prynne. With her infant daughter, Pearl in arms and the scarlet letter "A" (for adultery) on her breast, Prynne is taken from the town prison to the town center. It is believed that she has committed adultery and is going to be punished for that. The novel covers the women's history in the U.S. since 1640s:

The setting of the novel is Puritan New England, where notorious events occurred involving the persecution and execution of headstrong women. In 1637 Anne Hutchinson. . . was found guilty of treason and heresy. Her crime was holding "mixed" meetings of men and women where she clarified and commented upon sermons. In 1660 Mary Dyer, a member of the hated Quaker sect - which gave women a voice in religious meetings - was hanged on Boston Common when she persisted in returning to Boston to proselytize. (Johnson10)

By 1641, adultery was punishable by death, therefore, Hester's punishment is less than the one that the real female adulterers received (Johnson 10):

The penalty thereof is death. But in their great mercy and tenderness of heart they have doomed Mistress Prynne to stand only a space of three hours on the platform of the pillory, and then and thereafter, for the remainder of her natural life to wear a mark of shame upon her bosom. (Hawthorne 46)

Some critics, like [David S.] Reynolds, explore that when Hawthorne created Hester's character the emergent women's rights movement was challenging societal attitudes towards women:

She . devotes her life to the needy, especially women. She turns the meaning of her letter A from "adulteress" to "able," challenging the $19^{\text {th }}$ century division of women into either devils or angels. Hawthorne uses Hester to address not only the frequent unhappiness of domestic life but also limitations on women: as was true of many in the 1840 s, the only way Hester can make a living is a seamstress. (40) 
Hester's character, adamantly, speaks against the suppression of contemporary women and advocates a sense of independence for them through her sufferings and stance:

She had fortified herself to encounter the stings and venomous stabs of public contumely, wreaking itself in every variety of insult she longed rather to behold all those rigid countenances contorted with scornful merriment, and herself the object. . . she would become the general symbol at which the preacher and moralist might point, and in which they might vivify and embody their images of woman's frailty and sinful passion. Thus the young and pure would be taught to look at her. . as the figure, the body, the reality of sin. (Hawthorne 42-43,55)

Celebrating her badge of shame proudly, Prynne refuses to allow those in power to remove her child from her," 'I can teach my little Pearl what I have learned from this!' answered Hester Prynne, laying her finger on the red token" (Hawthorne 75). Her power is shown in her decision to remain unchanged in Boston:

She had returned, therefore, and resumed of her own free will. ... the scarlet letter ceased to be a stigma which attracted the world's scorn and bitterness, and became a type of something to be sorrowed over, and looked upon with awe, yet with reverence too. (Hawthorne 106, 165)

Carolyn R. Maibor thinks Hester's return as a counselor and reformer to Boston predicts the changing positions of American women as predicted in the text (80):

She assured them, too, of her firm belief that, at some brighter period, when the world should have grown ripe for it, in Heaven's own time, a new truth would be revealed, in order to establish the whole relation between man and woman on a surer ground of mutual happiness. (Hawthorne 166)

Prynne's prediction comes true. A generation later, Henry James declared: "The book was the finest piece of imaginative writing yet put forth in this country" (Idol Jr. 24). Hester is a real hero, who shows women how to transcend gender based biasness in a patriarchal society (Baym; The Scarlet Letter: A Reading, 62). Jamie Barlowe thinks that Hester has played a vital role in highlighting women's nuanced constraints (121). She "fulfils her rule as a prophetess, hastening the arrival of time when society will change to the benefit of women" (Maibor 80). John Dougherty and Kirk Johnson believe The Scarlet Letter has addressed the issues of forced marriage, which, in some ways, is still the part of the U.S. society, quoting polygamist Mormon sect leader Warren S. Jeffs, who, in 2006, forced the marriage of a fourteen year old girl against her wishes (122). In American fiction, she, for the first time, speaks against the suppression of contemporary women in terms of their social and sexual rights that proves quite an insight in the evolution of American feminism.

\section{Louisa May Alcott's Little Women (1868-69)}

Louisa May Alcott is an iconic $19^{\text {th }}$-centuryAmerican poet and novelist, best known for her novel, Little Women (1868-69). She was born in Germantown, Pennsylvania, on the 29th of November, 1832. Her parents, Both Abba Alcott and Branson Alcott expected a baby boy, but Louisa May Alcott was born instead (Anthony 16).Yet Louisa's character in some ways fulfilled this expectation of a male child. In her early education at home, she was more interested in playing with boys than girls and often attracted their attention. Once she was given a doll that did not interest her at all (Anthony 24-25).Instead, she fancied outdoor activities; her character, Jo, speaks from a similar affection when she says, "I do not like to doze by the fire, I like adventures, and I am going to find some" (Alcott 39).

Drawing on domestic experiences of her own time, Alcott's Little Women could be deemed a transitional book from the $19^{\text {th }}$-to the $20^{\text {th }}$ century. As a domestic drama, Little Women characterizes five versions of the late $19^{\text {th }}$ century American woman. The four daughters and the mother are in a micro-universe that is later joined to a larger male sphere. The novel ends at Marmee's sixtieth birth day, at which point Jo has two sons and Amy a daughter, Beth. Little Women offers a refuge to young women where they can seek guidance on how to balance their marital and day-to-day lives with their individuality. Nina Baym explains, "More adventurously, the novel 
explore[s] the question of gender and power, focusing on Jo's dissatisfaction with the constraints of girlhood and her efforts to become a successful writer" (1735; Vol. B).

Louisa May Alcott's Little Women has left a profound effect on its readers. When Louisa May Alcott visited Vassar College, she was amazed at the honorable reception she received from the students and was told that they had modeled groups on her fictional characters from Little Women (Anthony 205). Despite this favorable reaction, the novel's advocacy for women's liberty came to be seen as merely tepid. As a writer herself, the character Jo's artistic ambitions are converted into motherly responsibilities at Plumfield-an extension of the domestic sphere-where she is often referred to as "Mother Bhaer."Gloria Steinem argues in her book, Revolution from Within, about the supporting role that Little Women has played in the lives of numerous women since the time of its publication:

On the one hand, the book appeals to girls' need for intimacy and connection within a female group. It offers safety, security, a protected space in which to develop and grow. On the other hand the book appeals to the revolutionary or rebel within adolescents and preadolescent girls. (Keyser 14)

Charles Strickland puts it more precisely:

[T] he bulk of her fiction subscribed to the idea that cultured women hold an obligation peculiar to themselves to promote the moral regeneration of society through their influence as wives and mothers, which is to say that Alcott saw a reformed family as the key to a reformed society. (Keyser 22)

Though critics over the years have debated whether Jo is a loser or winner, she has served as a role model for countless readers. Alberghne and Clark state, "To engage with Little Women is to engage with the feminist imagination," which is mostly conveyed through the character of non-conformist Jo:

Some argue she provides a model of independence, even if she ultimately capitulates to marriage; others, that she embodies a sense of connectedness with a community of women. Some argue that she submits to prevailing cultural norms; others, that she connects them; others still, that she negotiates among competing norms. (xvii)

\section{Henry James's The Portrait of a Lady (1881)}

Born at a high-water mark in American history, Henry James Jr.'s (1843-1916) life affords a glimpse not only into the $19^{\text {th }}$-century literary circles, but also their relation to the massive social, economic, and political changes introduced by industrialization (Haralson and Johnson 3). James Jr.'s writing coincides with a particularly remarkable moment in U.S. history: "it begins with one period of vivid historic transition, and ends in another" (Graham 2). Writing for more than half a century, James's "writings include novels, novellas, tales, plays, autobiographies, criticism, travel pieces, letters, reviews, biographies"-almost a hundred books in total (Baym 388; Vol. C). In short, three of the major determinants in James's literary life are travel between America and Europe, the meeting of personal and literary friends in these diverse scenes, and engagement with the social issues of those scenes in his literature. Not the least of these, as we shall see, is the question of gender equality.

Minny Temple and, to some extent, his sister Alice, along with a handful of other inspiring women, would give birth to many of his fictional heroines, like Isabella Archer in The Portrait of a Lady and Milly Theale in The Wings of the Dove (Haralson and Johnson 5). The Portrait of a Ladyo scillates between doctrines of determinism and free will. The novel's milieu is a moment when "the 'new woman' was beginning to assert herself as a personage to be reckoned with" and its rebellious heroine reflects this social change (Powers 8). Far from being a work of pro-suffragist propaganda, however, the novel presents a far more nuanced portrait of the social options available for modern women. Isabel Archer, who favors independent life, is tricked into a disastrous marriage. Considering her own faults, she comes to realize that, in her undereducated position, she wrongly brushed aside the opinions of those with more real-world experience, like Mrs. Touchett, Ralph, and 
Henrietta; and that this led to her falling prey to Madame Merle and Osmond. This in itself is the supreme education for a heroine, according to James. After her realization, Isabel becomes psychologically free entirely. She defies Osmond and travels to London to see her dying cousin, Ralph. At the same time, she liberates herself from the clutches of an oppressive romance and returns to Rome, leaving Caspar Goodwood behind for the last time. With this newly attained psychological independence, she is able to protect herself and Pansy (Powers 1416).

The Portrait of a Lady "demands readers' trust and patience; it is a novel about 'seeing' and 'knowing'" (Crowley 10). Placing Isabel-who has "the audacity of Daisy Miller, the charisma of Christina Light and the moral intensity of Madame de Mauves" (Hutchison 57)-in Europe, James gives the novel an internationalist perspective that becomes crucial to understanding its content. It further "helps us to understand the context in which the novel was conceived and developed and gives us a good grasp of what materials were available to James in his creation of the story" (Crowley 11). It is difficult to say, finally, whether the novel is about Isabel or the Victorian society, but it is certain that the novel critiques the Victorian patriarchy in terms of marital issues (Crowley 11).

Isabel's independent, free-thinking spirit and her approach to marital compromise, make her a lifelike character, who has spoken not only for her own generation, but for generations of women after her. She may be, in some sense, weaker than some of her readers, but, at the same time, she strikes us with a certain indefinable charisma. Realizing the importance of her character, James further polished her psychological portrait in the revised edition of 1908, making her dialogue more effective and self expressive. As Cornelius Crowley notes, "What happens in The Portrait of a Lady is the 'ado' taking place within the consciousness of the heroine, Isabel Archer" (Crowley 17). Likewise, Hazel Hutchison argues that "it is the portrait of Isabel's expanding consciousness that is James's subject, and his carefully paced handling of this makes the novel the masterpiece it is" (57).

Part of the novel's reputation rests on its ambiguity: rather than supplying a clear-cut conclusion, when Isabel's portrait is finished, James leaves readers with a question: "what is she finally, and what has she become?" Is she a failure for having surrendered her individuality to Osmond or has she reached the peak of her maturity in a psychological independence from all men, including Caspar Goodwood ${ }^{2}$ ? James thus depicts her character aimed at unfolding an evolutionary process of growth to maturity. Furthermore, he tries to show readers how they, in turn, might go through such a process-how it looks, feels, and sounds in the real world offering a novel solution how to fight the hazards of a failed marriage. Though Isabel fights back well, she still remains a dilemma for readers, who must decide whether she is ultimately a winner or loser in the novel.

\section{Kate Chopin's The Awakening (1899)}

Born as Catherine O'Flaherty in St. Louis, Missouri, Kate Chopin (1850-1904) was the daughter of an Irish immigrant, who became a successful businessman and married into a socially prominent French Creole family"pure-blooded descendants of French and Spanish settlers"(Seyersted 13). Kate Chopin received proper social education at home where, at an early age, she was inspired by her father's gracious manner, her mother's gentility, and her great-grandmother's insight regarding the question of women's equality(Felder 79). Mme. Charleville, her great grandmother, polished Kate's many talents-like playing piano and storytelling. Father Daniel S. Rankin's Kate Chopin and her Creole Stories inform us that Mme. Charleville guided the young Chopin and told her regional inspirational stories about Louisiana history and strong-willed women that would produce an everlasting influence on her life and writing career.

${ }^{2}$ Being the son of a prominent Boston-mill-owner, he is Isabel's most dedicated suitor in America. 
More than any story, Chopin was enamored of this tale, with its heroine who leaves her brutal husband after giving birth to a son. She chooses to live with her lover, Laclede, without taking his name to avoid the troubles of law. Rankin confides, "It was the great-grandmother's influence that awoke a penetrating interest in character, particularly in independent, determined women" (Seyersted 17).

The Awakening, "first published as a disturbing, complex, and glaring truthful novel," was the last great novel of the $19^{\text {th }}$ century and one of the first influential books of the $20^{\text {th }}$ century (Levin: Introduction to The Awakening).Some critics contend that the book was inspired by some local events and other literary stories. Phanor Breazeale, Chopin's brother-in-law, believes that the author took the plot from the life story of a Creole woman, who had similar sexual passion. Maupassant's "Reveil" also bears a strong similarity to The Awakening. In "Reveil," the protagonist, Jeanne Veasseur, is a woman, who loves her husband, but he is sexually cold. As a result, she is attracted by another young man. Both "Reveil" and The Awakening can be classed alongside Gustave Flaubert's Madame Bovary (1856), in their explorations of female characters' forbidden passion. Diana Epelbaum notes an additional influence:"As a patchwork of nineteenth-century fictional styles, and as an early iteration of regional, realistic, and naturalistic writing, [Elizabeth Stoddard's] The Morgesons stands firmly as a precursor to [Chopin's] The Awakening" (Seyersted123). Verify

The Awakening, until the end, revolves around Edna's gradual awakening to her status as an individual in the society she lives in"(Seyersted 135). The text attests "Her marriage to Mr. Pontellier was purely an accident" (Chopin 23). He fell in love with her; she liked him and was flattered by his devotion. She thought they had much in common, but once married, she found out it was not so. In a way, she grew fond of her husband, however, realizing with some unaccountable satisfaction that no trace of passion or excessive and fictitious warmth colored her affection, thereby threatening the marriage's dissolution. After the marriage, Mr. Pontellier wraps Edna in material comfort and fixes her in the constraints of Victorian domesticity. She grows restless and starts questioning her sexual, emotional, social, and individual freedom. The more she exercises her sexual freedom, the more her relation with her family turns sour. Even her lover, Robert Lebron, is no match for her passion and escapes to Mexico. Her awakening leads to her dissatisfaction, causing her to neglect both her hobbies and her domestic duties. She decides to live apart from her family at her own expense to safeguard her individuality and to satisfy her sexual impulsesif not necessarily her restless passion for ultimate individualism, with Alcee Arobin. In some ways, he also turns out, like her husband, to be less charming than she thought, and she loses her faith in him. Robert returns, but he is unable to accept her individual autonomy. She realizes that her patriarchal society is quick to condemn a freedom-seeking woman who neglects her children since sherather than her husband-is "intended by nature" to take care of them. She plans something uniquely individualistic in the history of female literary characters to preserve both her family's reputation and her freedom.

Chopin touched on many social problems, but the areas related to marriage and women's sexual issues were explored in great depth. Per Seyersted notes: "In exposing the narrow marriage rules and the exaggerated belief in ethical will power, the author tries to be not too direct" (118). She explores psychological nuances and the question of women's equality. She was "fascinated by women who dared to defy conventions and strike out their own. She mostly depicted repressed passion and frustrated women"(Seyersted101). Most of her characters are rebellious and aspire to be independent, like Mademoiselle and Edna in The Awakening (1899); "that speaks radically to issues of gender, sexuality, and the American family"(Felder 80-81). As Syersted observes, "Chopin's treatment of female sexuality is more complete and "more convincing" than that of any American novelist to date, and he praises the fundamental seriousness of the novel" (Martin 13). Chopin earns her place in the fin de siècle American literary canon by being the first woman writer in her country to accept passion as a legitimate subject for serious, outspoken fiction, and to present the unsparing truth about a woman's hidden life. 


\section{Theodore Dreiser's Sister Carrie (1900)}

Theodore Herman Albert Dreiser (1871-1945) was born the eleventh of thirteen children in Indiana, USA. Arun P. Mookerjee explains, "Born in the gilded age of millionaires, Dreiser could taste only poverty and hardships and wistfully looked at the splendor and luxury of the wealthy" (10). His father, John Dreiser, left Germany to escape military service. He came to the new land with a dream of prosperity that he had never had before. However, his economic condition constantly fell from bad to worse. Two years before Theodore Dreiser's birth, his father lost his wool factory in a fire, and John Dreiser was not able to support his large family. Consequently, the children went in diverse directions to earn their bread. Economically wretched and frustrated, John Dreiser tried to impose rigid discipline and conventional Catholic ideas on his children, who openly rebelled against them. Paul Dreiser chose music, and Rome Dreiser got involved in gambling. Comparatively economically stable, Paul often helped the family in hard times and provided considerable help to Theodore and Emma in their desperate struggle for survival (Sloane 23). Meanwhile, the daughters entangled themselves in romantic affairs, resulting in two of them getting pregnant. John Dreiser banished them from the house, but they were sheltered by theirmerciful mother, Sara Schanab, who "was the very embodiment of self-love, devotion, charity, forgiveness, and a very liberal look ... whom he [Dreiser] worshiped" (Mookerjee 13).

Sister Carrie(1900), which reflects Dreiser's life and career from his birth to the publication of the book," is considered a memoir of Dreiser and his family's dire struggle in industrialized urban America. Dreiser's autobiography, Dawn (1931), details that in Sister Carrie, Dreiser tells the story of his early economic impediments as well as that of his own sisters-particularly his elder sister, Emma — whose wayward lives and illegitimate children furnished him with the ideas he would write about (Pizer, New Essays 5). Donald Pizer relates that the respective rags-to-riches and riches-to-rags trajectories of Carrie and Hurstwood embody Dreiser's own aspirations and fears from his struggling days. He yearned to become Carrie and feared he would become Hurstwood. Carrie Meeber, the central character of the novel, comes from Wisconsin to Chicago to support herself like other young women of the time. In keeping with the rule of the day, her exploitation starts on the very train she travels on:

The train was just pulling out of Waukesha. For some time she had been conscious of a man behind. She felt him observing her mass of hair. He had been fidgeting, and with natural intuition she felt a certain interest growing in that quarter. (Dreiser 2)

In Chicago, she falls prey to Charles Drouet, who makes acquaintance with her on the train, and George Hurstwood. The manager of Fitzgerald and Moy, Hurstwood is a married man with two children. After stealing ten thousand dollars from his employer's saloon, Hurstwood tricks Carrie into fleeing with him to New York. On being discovered, he returns the money, but slips into hard times and finally becomes homeless. Dreiser describes how far Hurstwood had fallen: "At . . two charities, during the severe winter which was now on, Hurstwood was a frequent visitor. On one occasion it was peculiarly cold and finding no comfort in begging about the streets, he waited until noon seeking this free offering to the poor" (Dreiser 359). Later on, unbeknownst to Carrie, Hurstwood commits suicide.

In contrast to Hurstwood's downward spiral, Carrie rises in her stage career, not hesitating to give out sexual favors to make her dream of becoming a celebrity come true. In his essay, "A Star is Born: 'Celebrity' in Sister Carrie," Philip L. Gerber argues that the modern meaning of "celebrity" was refined by Dreiser in Sister Carrie, where he uses the word for the publicized notables who frequently visit saloons, restaurants, and theaters. Toward the end of the novel, the word is defined more categorically: what Carrie becomes is called a celebrity, a subject of newspaper discussion (2).

Carrie's character proves an embodiment of self-reliance and independence for the modern American womanthe new woman. Mukherjee in his essay, "Sister Carrie at Ninety: An Indian Response," argues that Sister Carrie was not for the 1900s, but for an everlasting phenomenon that the century has propagated. It is the story 
of every society that is swept by modernization and industrialization, where many young women like Carrie fall prey to the fangs of capitalism and consumerism (27).

\section{Conclusion}

The Scarlet Letter, Little Women, The Portrait of a Lady, The Awakening, and Sister Carrie have collectively, step-by-step, contributed their share to transforming American women's position with their realistic protagonists-Hester Prynne, Jo March, Isabel Archer, Edna Pontellier and Carrie Meeber through the mid 19 $^{\text {th }}$ and early 20th century. Hester Prynne could be called the pioneering literary column of American feminism. She, for the first time, demands women's social and sexual rights changing the percept of sin and marriage in common minds. So here she gives birth to a new woman, who challenges the patriarchal shackles. Being anostracized and fallen woman, she stands firm to re-win public opinion in her favor. The same problem exists in contemporary Pashtun society; where Hester Prynne's character, in terms of marriage consent, divorce, political rights, and self reliance; could do miracle for the suppressed Pashtun sisters. Majority of Pashtun women silently accept the injustices done to them because in their opinion saying no to their mentant amount to sin. Hester Prynne's persona has the ability to give them voice across the Pashtun belt in Pakistan who will be able to openly challenge concepts based on gender biasness. Jo March, who at the beginning seems quite revolutionary challenging many patriarchal constraints, wants to remain single as well as independent. She leads a peaceful and economically independent life after marrying the man who is her ideal image of a husband and establishing her own school. Her character reflects a broader image of contemporary women's understandings of the institution of marriage and the professional sphere, which were still in the clutches of the Victorian code - a societal code of life having strident constraints for women). Jo bears strong similarities with many Pashtun women but they do not have opportunities like her. Her balanced character could inspire the Pashtun women to challenge thelines of discrimination between women and men-especially the freedom of movement, thought suppression, economic dependency and gender-peppered discrimination. Isabel Archer seems to carry the question of women's equality in regard to the constraints of marital life a step further than Jo March. Like the new woman of the day, Isabel wants to be an independent and single woman regardless of the social stigmas attached to those conditions, but she ends up in an unhappy conventional marriage. Though unhappy, she returns to Osmond, forming another feminist narrative detailing how to fight the odds of a bad marriage whose break-up could doom the lives of many innocent individuals like Pansy, who are directly or indirectly associated with it. Isabel's character seems the most suitable guide for the Pahtun women. Like Isabel, Many Pashtun women slip into marital ties that are highly unsuitable for them. Though the exact percentage is not known, the majority of Pashtun women are suffering in the shackles of arranged/conventional marriages. Considering divorce a cultural taboo, the Pashtun culture does not offer any solution to women's marital problems-besides force to be silences. In this regard, Isabel could inspire the Pashtun sisters in two ways. At first place, her own failed marital decision warns how to escape fortune seekers and misogynists like Osmond. Second, through her final decision, she guides how to fight back pragmatically in such marital quagmires where they have no way out.Edna Pontellier invites us to investigate another angle of the question of equality for women. Like Isabel Archer, she mistakenly becomes enamored of Léonce's masculine charms and ends up suffering the perils of a conventional marriage. Instead of remaining in mental and emotional torture throughout her life, Edna makes a unique decision to protect both her freedom and her children's identity from damage. She takes her life in the most fascinating way, for which English literature is unable to provide a precedent. In some ways, Edna's character fixes well in Pashtun culture. Like Edna, to save their family honor, many Pashtun women commit suicide owing to their multi-faceted marital and sexual issues. Even the suicide of a Pashtun woman is considered a social stigma for her family and clan; consequently, events like these are hushed to avoid humiliation. Brushing aside her suicide for personal emancipation, Edna can encourage the Pashtun women to show carefulness in selecting their life-partners, and have right to their thoughts, body and sexual feelings-avoiding submission to sex out of duty. Taking the question of women's equality to the extreme, Carrie Meeber, the protagonist of Sister Carrie, uses her body and freedom as currency to reach the social heights of which she has always dreamt. This focus on Carrie's control over her own body made the novel of particular interest to the generation 
of feminist, who grew after the second World War. Carrie's character addresses women's economic and harassment issues. She could prove fruitful in awakening the economic self-reliance in Pashtun women, who are in worse economic perils. Apart from her sexual favors, her character can teach patience as well as ways to the Pashtun women how to survive and rise through the Darwinist-chauvinist ebbs and flows of the contemporary society, which considers a woman no more than a sex toy. Hester Prynne, Jo March, Isabel Archer, Edna Pontellier and Carrie Meeber could serve as role models for the emerging Pashtun women and activists. As these protagonists address the woman's question from nuanced angles, the insight will transform the vision of Pashtun women in many (above-mentioned) ways in Pakistan. This greater vision will also inspire the native contemporary literary writers to reflect on women's issue in the same way to contribute some change to women's social, personal, economic and political position by contextualizing Pashtun women's struggle in an international contest.

\section{References}

Alberghene, Janice M. and Beverly Lyon Clark, eds.. Little Women and Feminist Imagination: Criticism, Controversy, Personal Essays.. New York: Garland Publishers. 1991. Print.

Alcott, Louisa May. Little Women. Ed. Claire Booss. New York: Gramercy Books, 1982. Print.

Anthony, Catherine. Louisa May Alcott. New York: Alfred A. Knopf, 1938. Print.

Barlowe, Jamie. The Scarlet Mob of Scribblers: Reading Hester Prynne. Illinois: Southern Illinois University Press, 2000. Print.

Baym, Nina, Jeanne Campbell Ressman and Arnold Krupat, eds. The Norton Anthology of American Literature. New York: Norton \& Company, Vol. C, Seventh Edition, 2007. Print.

Baym, Nina, Robert S. Livine, eds. The Norton Anthology of American Literature. Ed. Julia Reidhead. New York: $\quad$ Norton and Company, Vol. B, $8^{\text {th }}$ Edition, 2012. Print.

Baym, Nina. "Hester as a Hero" Social Issues in Literature: Women's Issues in Nathaniel Hawthorn's The Scarlet Letter. Ed. Claudia Durst Johnson. New York: GALE CENGAGE Learning, 2009. 67-73. Print.. The Scarlet Letter: A Reading. Boston: Twayne Publishers, 1986. Print.

Chopin, Kate. The Awakening. New York: Barnes \& Noble, 1995. Print.

Crowley, Cornelius. Henry James: The Portrait of a Lady. Paris: Didier Erudition, 1998. Print.

Dougherty, John and Kirk Johnson. "The Forced Marriage" Social Issues in Literature: Women's Issues in Nathaniel Hawthorn's The Scarlet Letter. Ed. Claudia Durst Johnson. New York: GALE CENGAGE Learning, 2009. 122-126. Print.

Erlich, Gloria C. " Hawthorne's Family Impact" Social Issues in Literature: Women's Issues in Nathaniel Hawthorn's The Scarlet Letter. Ed. Claudia Durst Johnson. New York: GALE CENGAGE Learning, 2009. 2533. Print.

Felder, Deborah G. A Book Shelf of our Own: Works that Changed Women's Lives. New York: Kensington Publishing Corp, 2005. Print.

Fetterly, Judith. The Resisting Reader: A Feminist Approach to American Fiction. Bloomington and London: Indiana University Press, 1977. Print.

Greenblatt,Stephen. Will in the World: How Shakespeare Became Shakespeare. New York: W. W. Norton \& Company, 2004. Print.

Haralson, Eric and Kendal Johnson. Henry James: A Literary Reference to his Life and Works. $\quad$ New York: Facts on File, 2009. Print.

Hawthorne, Nathaniel. The Scarlet Letter. Ed. Leland S. Person. New York: W. W. Norton and Company, 2005. Print.

Hutchison, Hazel. Brief Lives: Henry James. London: Hesperus Press Limited, 2012. Print.

Idol Jr., John L. "The Life of Nathaniel Hawthorne" Social Issues in Literature: Women's Issues in Nathaniel Hawthorn's The Scarlet Letter. Ed. Claudia Durst Johnson. New York: GALE CENGAGE Learning, 2009. 17-24. Print.

James, Henry. The Portrait of a Lady. London: Marshal Cavendish Ltd. 1987. Print. 
Johnson, Claudia Durst, ed. Social Issues in Literature: Women's Issues in Nathaniel Hawthorn's The Scarlet Letter. New York: GALE CENGAGE Learning, 2009. Print.

Kesterson, David B. " The Hawthorne-Fuller Friendship " Social Issues in Literature: Women's Issues in Nathaniel Hawthorn's The Scarlet Letter. Ed. Claudia Durst Johnson. New York: GALE CENGAGE Learning, 2009. 34-38. Print.

Lyall H. Powers, ed. The Merill Studies in The Portrait of a Lady. Ohio: Charles E. Merrill Publishing Company, 1970. Print.

Maibor, Carolyn R. "A Woman's Calling" Social Issues in Literature: Women's Issues in Nathaniel Hawthorn's The Scarlet Letter. Ed. Claudia Durst Johnson. New York: GALE～CENGAGE Learning, 2009. 80-87. Print.

Martin, Wendy, ed. New Essays on The Awakening. New York: Cambridge University Press, 1988. Print.

Mookerjee, R.N. Theodore Dreiser: His Thought and Social Criticism. Delhi: National Publishing House, 1974. Print.

Pakistan Poverty Alleviation Fund (PPAF). Development Profile of Swat District: Situation Analysis \& Baseline Surveys for Poverty Reduction through Rural Development in KPK, FATA \&Balochistan . AASA Consultant: Karachi, 2015. Web. 2 November 2017.

Reynolds, David S. " Hester and Feminists of the 1840s" Social Issues in Literature: Women's Issues in Nathaniel Hawthorn's The Scarlet Letter. Ed. Claudia Durst Johnson. New York: GALE CENGAGE Learning, 2009. 40-47. Print.

Rampton, Martha. "Four Waves of Feminism."Pacific Magazine. Fall 2008. Pacific University Center for Gender Equity. pacificu.edu. Web. 3 July 2017.

Sanauddin, Noor. Proverbs and Patriarchy: Analysis of Linguistic Sexism and Gender Relations among the Pashtuns of Pakistan. Diss. University of Glasgow, 2015. theses.gla.ac.uk. Web. $30 \quad$ October 2017.

Seyersted, Per. Kate Chopin: A Critical Biography. Baton Rouge: Louisiana State University Press, 1969. Print. Sloane, David E. Sister Carrie: Theodore Dreiser's Sociological Tragedy. New York: Twayne Publishers. 1992. Print.

Tomasek, Kathryn Manson, and Elizabeth Lennox Keyser." A Great Happiness: Searching for Feminist Utopia in Little Women." Little Women and Feminist Imagination: Criticism, Controversy, Personal Essays. Eds. Janice M. Alberghene and Beverly Lyon Clark. New York: Garland Publishers. 1999. 237-259. Print.

Yousafzai, Malala. I am Malala: The Girl who Stood up for Education and was Shot by the Taliban. Ed. Christina Lamb. London: Little, Brown and Brown, 2013. Print.

Yousafzai, Malala. Personal (Telephone) Interview. 23 August 2015. 